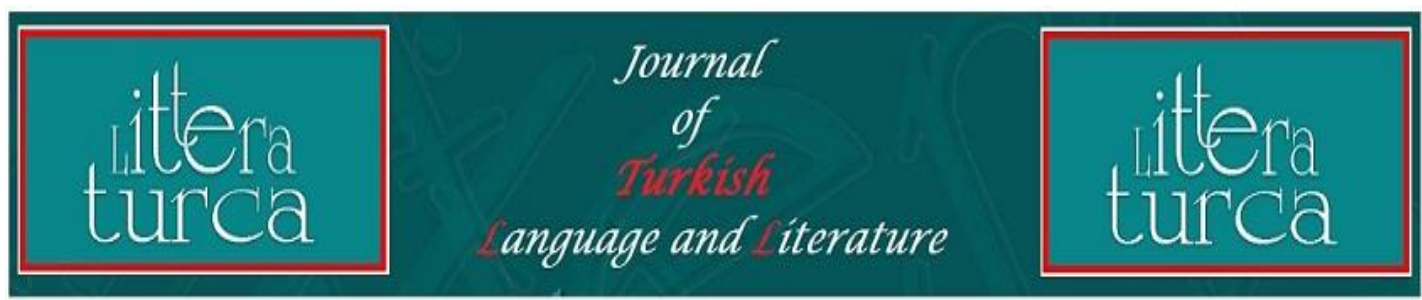

\title{
ANADOLU SAHASI VE KIRGIZ FOLKLORUNDA YALANLAMALAR VE İ̧LEVLERi
}

\author{
İsmail ABALI ${ }^{1}$
}

Özet

Tarihi süreci içinde folklorik ürünler, işlev ve ihtiyaca bağlı olarak farklı türler dahilinde bulunabilir ve bu çeşitlilik, toplumlar ve boylar bağlamında değişiklik gösterebilir. Aşık fasıllardan biri konumunda bulunan yalanlamalar için de durum aynıdır. Kırgız halk edebiyatında müstakil bir tür halinde karşımıza çıkan ve yer yer bazı masallar dahilinde de yaşabilen yalanlamaların Anadolu Türk folklorundaki versiyonlarının inceleneceği bu çalışmada, ayrıca, söz konusu yalanlamaların hangi fonksiyonlara sahip olduğu ve hangi ihtiyacı karşıladığı gibi sorulara cevap aranacaktır. Bu incelemeler, yalanlama örnekleri ile pekiştirilecek ve çalışmamızın sonunda ise konuyla ilgili birtakım öneriler sunulacaktır.

Anahtar Kavramlar: Yalanlama, Aşık Edebiyatı, Kırgız Folkloru.

\section{THE LIES* AND ITS FUNCTIONS BELONG TO ANATOLIAN AND KIRGHIZ FOLKLORE}

\section{Abstract}

In the historical process, the folkloric products can exist in different types according to functions and needs, also should indicate variations in the context of societies and clans. It is the same of the lies which is one of the minstrel episodes. In the study, the lies occuring as several types in Kirghiz folklore and sould live in certain tales will be analysed; also will sought the questions including have which functions and requirements. These analysings will be established with patterns and some advices about the issue will be indicated.

Keywords: The Lie, the Minstrel Literature, Kirghiz Folklore.

1 Dr., Milli Eğitim Bakanlığı, Türk Dili ve Edebiyatı Öğretmeni, the_hoca0986@hotmail.com.tr.

* A type of poem belongs to Turkish folk literature which includes incredible lies.

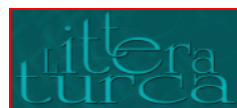

Journal of Turkish Language and Literature

Volume:2, Issue: 1 , Winter 2016, (1-12)

Doi Number: 10.20322/It.06691 


\section{Giriş}

Dinen günah, ahlaken ayıp olarak bilinen yalan, bütün toplumlarca zararlı görüldüğü için yasaklanmıştır. Gelmiş geçmiş tüm dinlerin kutsal kitaplarında, didaktik eserlerde (Karaköse 2014: 129-132) ve milletlerin sözlü ürünlerinde bu zararlı özelliğinden bahsedilen yalanın Türk folklorunda yüceltildiği ve bir halk bilgisi olarak değerlendirildiği farklı bir versiyonu ise çalışmamızın araştırma konusu olan yalanlamadır.

Anadolu sahası Türk halk edebiyatında aşık fasıllarından biri olarak bilinen, Kırgız folklorunda ise hem müstakil hem de masalların (comok) bünyesinde yaşayan bir tür olarak karşımıza çıkan yalanlamalar hakkında Umay Günay (1999: 57);

"Aşık fasıllarında yalan söylemeye dayanan en çok ve inanılmaz yalanları bulup söyleme sanatı aynı zamanda kelime hazinesindeki zenginliği ortaya koyma bakımından da ilgi çekici bir bölümdür. Anonim halk edebiyatı ürünleri arasında çok kere yalana dayalı tekerleme türü ile aşık deyişleri arasındaki yalanlamalar arasında bir bağ olduğu düşünülebilir. Tekellümün bu kısmı da karşılıklı paylaşılan koşma dörtlüklerden oluşur. Aşık fasılları içinde çok sık yer alan bir deyişme çeşididir. "

şeklinde bir değerlendirme yaparak yalanlamaların içeriği, işlevi ve yapısı üzerinde durmuştur. Doğan Kaya da (2007: 88-89) yalanlamaların işlevine dikkat çekmiş ve;

"Aşıkların gulüv derecesinde inanılmaz yalanları sıralamasıdır. ... Meclistekiler bunları dinlerken hoşça vakit geçirir, aşıkların gücünü tayine çalışır. Yalanlama sırasında söylenen sözler çoğu zaman sürrealist yaklaşım olarak değerlendirilmiştir. Ancak aşıklar, çeşitli mecazlar ve remzler yoluyla söyledikleri bu yalanların aslında gerçeğin gizlenmiş şekli olduğunu ifade ederler. Sürrealizm örneği olarak görülen yalanlamaları bir yalan değil de gerçeği vurgulayan birtakım remz ve mecaz olarak görmek gerekir. Sarf edilen rumuzlu ifadelerin her biri bir gerçeğe işaret eder."

sözleriyle, söylenen bu yalanların gerçeğin gizlenmiş şekli ve sembolü olduğunu ifade eder. Ali Duymaz (2002b: 108), yalanlamaların en önemli özelliğinin yalan, hayal, abartı ve olağanüstülük olduğunu ifade ederek konuyu işleyiş tarzı yönüyle diğer metinlerden ayrıldığını belirtir. Duymaz, ayrıca, söz konusu türde sarf edilen yalanların günlük yaşamda kullanılan yalan ifadelerden farklı olduğunu ve yalanlamalardaki yalanların uzlaşmacı bir nitelik taşıdığını zikrederek söyleyen ile dinleyicinin arasında bir anlaşma bulunduğu belirtir (2002b: 114). Gerçekten de aşık, dinleyenlerin gözlerinin içine baka baka yalan söylemekten çekinmez. Hatta söylediklerinin yalan olduğunu en başta belirtir:

Hengâmi bu cengin mehdin eyledim

Hafya deryasını gezip boyladım

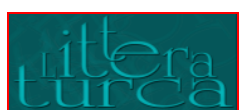

Journal of Turkish Language and Literature

Volume:2, Issue: 1, Winter 2016, (1-12)

Doi Number: 10.20322/It.06691 
Yalan yanlış bu destanı söyledim

Ömrümde demedim böyle yalanı (Çobanoğlu 2000: 313)

Aynı durumun Kırgız folklorunda da yer aldığını şu örneklerden öğrenmekteyiz:

"Yalan masal siz de söyleyin ben de söyleyeyim" (Baldar Folkloru 2002: 128)

"Yalan söyleyerek gencin, yaşlının hoşuna gittim" (Baldar Folkloru 2002: 129)

Konuyla ilgili olarak Erman Artun (1996: 33), yalanlamaların Türk halkının sağduyusu ve iğneleyici özellikleri neticesinde vücut bulduğunu, toplumsal bir eleştiri amacıyla ortaya çıktığını, eğlendirirken düşündürdüğünü, halkın sıkıntılarını konu edindiğini ve tüm bunları mizahi bir anlatımla dile getirdiğini belirtir.

Türk folklorunda yalanlama söyleyen aşıkların başında Hengami, Hacı Karakılçık, Kara Mehmet, Kamili, Şıhlıoğlu gibi ozanlar gelmektedir. Bunların dışında, aşık olmayan fakat yalancılıkları ve palavraları ile ün salan, halk içinden çıkmış kimseler de vardır. Kırkyalan Köse, Teyo Pehlivan, Kırkyalan Memiş gibi adlarla öne çıkan bu tipler, söyledikleri yalanlar ve palavralar ile yaşadıkları bölgelerde halkın ilgi ve dikkatini çekmiştir.

Anadolu sahası Türk folklorunda "yalanlamalı/mübalağalı destan" adıyla bilinen bu tür, Kırgız folklorunda ise "kalp (yalan)" olarak zikredilir. Konuyla ilgili olarak Kırgız Adabiyatı Entsiklopediyalık Okuu Kuralı adlı eserde (2004: 101);

\footnotetext{
"Insanın hayal gücünde yaratılan, akılla bağdaşmayanı gerçekmiş gibi kılan şiir. Halk dilinde deyiş niteliğindeki şifahi edebiyatın ezeli temellerinden. Halk şiiri çerçevesinde kalıplaşan türler arasında yer alır. Yalanlamalar, müstakil olabileceği gibi başka türlerin içinde de bulunabilir. Başka bir tür içerisine gizlenip bu şekilde de yaşayabilir ve bu türlerle birliktelik oluşturarak bir evrensellik kazanır."
}

şeklinde tarif edilen yalanlamanın hayal ürünü olduğu, çoğunlukla ayrı bir tür olarak bilindiği fakat başka türlerin de içinde bulunabileceği ifade edilmiştir. Yine eserde yalanlamanın Kırgız kültüründe çokça yayılmadığı ve bunun sebebinin ahenksiz bir söylenişi olduğu, belli bir temasının bulunmadığı ve her sözün kendince ayrı bir anlama sahip olduğu örneklerle açıklanmış; insanları eğlendirme amacını taşıdığı ve bazılarının varyantlaşmış olduğu ifade edilmiştir (2004: 102).

Kırgız Etnografiyası Boyunça Sözdük adlı eserde ise yalanlama, çocuk folkloruna ait bir halk yaratması olarak tanımlanmıştır. Gerçek dışı ve akla sığmayan olayları konu ettiği belirtilen yalanlama hakkında pek fazla bilgi bulunmayan eserde, ayrıca, Kırgızların "Koca Sinek", "Oğlan Sinek", "Çekirgeye Binen Adam", "Kırk Ağız Yalan" adında pek çok meşhur yalanlaması olduğu bilgisi de verilmektedir (2005: 135).

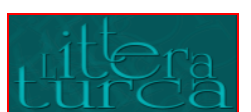

Journal of Turkish Language and Literature

Volume:2, Issue: 1, Winter 2016, (1-12)

Doi Number: 10.20322/It.06691 


\section{Yalanlamaların Tür Meselesi}

Eski devirlerden itibaren insanoğlu, sözlü ürünlerini nesilden nesle taşımış; bu taşıma esnasında sözlü ürünler değişik nedenlerle çeşitli türlere ayrılmıştır. Mitten destana, destandan masala, masaldan hikayeye dek süren bu ayrışım, folklorik işlev ve bağlamdan da etkilenerek günümüze kadar devam etmiştir.

Çalışmamıza esas olan yalanlamalar için de durum böyledir. Anadolu sahası ve Kırgız Türk folkloruna genel bir gözle baktığımızda, yalanlamaların müstakil bir tür olması yanında masal, fıkra, türkü, tekerleme gibi diğer türlere de aksettiğini görmekteyiz. Araştırmamızın bu kısmında yalanlamaların tür meselesine değineceğiz.

Yalanlamaların, söz konusu etkileşim içerisinde en çok masalla ilişkili olduğu ortadadır. i̇lk bakışta bile fark edilebilen bu durum, şüphesiz, masal tekerlemeleri ile alakalıdır. Konuyla ilgili olarak Münir Cerrahoğlu (2011), yalanlamalar ile masal tekerlemeleri arasındaki benzerliklerden birini, söz konusu iki türün birbirine kaynaklık ettiği ve masal anlatıcıları ile aşıkların etkileşimde bulunarak ürünlerini şekillendirdiği yönünde ortaya koymuştur. Gerçekten de "Şu yalan, bu yalan... Fili tuttu bir yılan, Karıncanın yedi yerinden çektim kolan, karıncaya bindim, deveyi kucağıma aldım, o da mı yalan?..." (Boratav 2000: 39) masal tekerlemesi ile "Yular bağladım kuşun boynundan/Nargile bağladım sineğin kayışından/Yalan masal siz de söyleyin ben de söyleyeyim..." (Baldar Folkloru 2002: 130) Kırgız yalanlamasının birbirinden etkilendiği yahut birbirine kaynaklık ettiği açıkça görülmektedir.

Ali Duymaz'a göre (2002a: 97) söz konusu etkileşim türkülere de aksetmiş ve "Çekirge Türküsü", "Sıçan Türküsü", "Tahtakurusu Türküsü"nde bu durum kendini göstermiştir. Bir Kastomonu türküsü olan "Tiridine Bandım" da geçmişte bir yalanlama olsa gerektir. Sözlerinin (Sabahleyin erken çifte giderken/Öküzüm torbadan düşmüş gördün mü/Manda yuva yapmış söğüt dalına/Yavrusunu sinek kapmış gördün mü) bir yalanlama örneğini andırdığı söz konusu türkünün teşekkül rivayetlerinden birinin aşıklar arasındaki bir yarıştan ortaya çıktığını (Akman 2013: 450) içermesi nedeniyle bu türkünün de Duymaz'ın görüşüyle paralellik gösterdiği ortadadır.

Yalanlamaların etkileşimde bulunduğu türlerden bir diğeri ise tekerlemelerdir. Anlamlı ya da anlamsız sözcüklerden oluşan tekerlemeler, başka türler içerisinde bulunabilir ve pek çok konuyu ihtiva edebileceği gibi yalanlamaları da içerebilir. Nerin Köse (2002), "Tür ve Fonksiyon" adlı yazısında yalanlama içeren bu tekerlemelerin farklı türler dahilinde farklı isimlerle bilindiğini örneklerle ortaya koymuştur. Bu türün halk hikayelerinde karavelli, döşeme; Karagöz ve Orta Oyununda yalan, tekerleme; meddahlıkta ise yabancılaştırma tekniği olarak adlandırıldığını ifade eden araştırmacı, anlatıcının kendi başından geçmiş gibi anlatmasının ise "yol yalanlamalı masal" şeklinde anıldığını belirtmekte; söz konusu türleşmenin işlev ile sıkı sıkıya bağlı olduğunu zikretmektedir. Bunun yanında Bülent Arı (2013), Gelin-kaynana manileri ile yalanlamalı destanları mizahi yönden karşılaştırmış, fakat iki türün sadece mizahi olarak birbirine benzediğini ifade etmiştir.

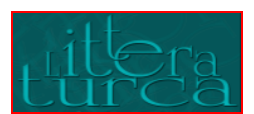

Journal of Turkish Language and Literature

Volume:2, Issue: 1, Winter 2016, (1-12)

Doi Number: 10.20322/lt.06691 
Görüldüğü gibi Anadolu sahası Türk folklorunda yalanlamalar, genellikle, başka türler içerisinde yer almakta; aşık fasıllarının tekellüm kısımlarında söylenenler ise "Yalanlamalı Destanlar" olarak adlandırılmaktadır. "Giriş" kısmında ayrıntılı bilgi verdiğimiz bu yalanlamalı destanlar, herhangi bir tür dahilinde değil müstakil bir tür olarak hala yaşamaktadır. Fakat son dönemlerde özellikle elektronik ortamda e-folklor ürünü (Bkz. Güvenç 2014) olarak yayıımaya başlayan yeni bir tür, yalanlamaların tekrar müstakilleşmeye başladığını işaret etmektedir:

Sene 1900. Deden bilmez ama baban iyi bilir. Salı günü cuma namazından çıktıktan sonra, atın üstünde yaya harbe gitmiştik. Çölde kar diz boyu. Karşımda düşman askeri. Çektim kılıcımı, iki el ateş ettim; 3 kişiyi vurdum, 7'si öldü. 10'unu gömdüler. Yaralıları hastaneye yetiştirmek için ambulansı aramamı gerekiyordu. Ama 1900'de telefon nerede? Ne yapsak diye düşünürken birden dedem I-Phone'u çıkarıp 11833'ü aradı. Ve bize bir ambulans gönderdiler. Hastaneye son sürat gidiyoruz, fakat depoda damla benzin yok. Ambulansın ani bir fren yapmasıyla kafamı çarptım, kolum kırıldı ve bacağımı alçıya aldılar. Nihayetinde eve geldim fakat evde elektrikler kesilmişti. O gün mum ışığında televizyon izledik. (www.uludagsozluk.com)

Son dönemlerde gerek kısa mesaj gerekse internet üzerinden yayılan bu ve bunun gibi güldürme amaçlı yeni yalanlamalar, kültürümüzün çağa göre birtakım değişimler geçirmiş olduğunun en açık göstergelerinden biridir. Bu anonim ürünler, ayrı bir tür olarak ve birçok yönden değişmeler göstererek yeniden yayılmaya başlamıştır.

Yalanlamalar, Kırgız folklorunda da müstakil bir tür olarak bilinmektedir. Gerek manzum gerekse mensur şekilde karşımıza çıkan bu ürünler, Anadolu sahası Türk folklorundaki yalanlamalarla ortak bir geçmişe sahip olup bir kısmı masalların (comok) içerisinde hala yaşamaktadır.

\section{Yalanlamaların işlevleri}

Halk edebiyatı yaratmalarının hangi ihtiyacı karşıladığı ve bu bağlamda hangi işlevi yerine getirdiği konusunda araştırmalar yapan W. Bascom, bu hususla ilgili olarak bir model oluşturmuş ve halk bilgisi ürünlerinin fonksiyonlarını şu şekilde belirlemiştir:

- Eğlenme, eğlendirme ve hoşça vakit geçirme işlevi

- Toplumsal kurallara ve törenlere destek verme işlevi

- Eğitimin ve kültürün genç kuşaklara aktarılması işlevi

- Toplumsal ve kişisel baskılardan kurtulma işlevi (Ekici 2011: 124-125)

İşlevsel halkbilimi araştırmalarına temel olan Bascom'un bu dört maddesine Illhan Başgöz, beşinci bir işlev eklemiş ve folklor ürünlerinin protestolara ve başkaldırmalara da destek verdiğini ifade etmiştir (1996: 2).

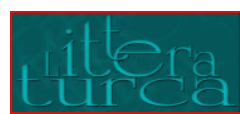

Journal of Turkish Language and Literature

Volume:2, Issue: 1, Winter 2016, (1-12)

Doi Number: $10.20322 /$ It.06691 
Yapı ve tür olarak çeşitli şekillerde karşımıza çıkan yalanlamalara işlevsel açıdan yaklaşı̆ı̆ımızda söz konusu türün birçok fonksiyonu yerine getirdiği açıkça görülmektedir. Akla, hayale sığmayan yalanların bir araya getirilmesiyle oluşturulan ve oldukça mübalağalı bir anlatıma sahip olan yalanlamaların, dinlerlerken insanları güldürdüğü ve anlatan/söyleyen kişi tarafından bir eğlence aracı olarak kullanıldığı malumdur. Nitekim Kara Mehmet'in "Senede kırk dönüm bostan ekerim/Benden başka kimse yemesin derim/Kavunu karpuzu kabuklu yerim/Acelemden soyamıyorum doktor bey" (Artun 2000: 335) dizelerini de içeren "Tokdur Bey" ile "Bağlasam sökerdi çamın kökünü/Yalnız yerdi otuz dönüm ekini/Götürürdü bir trenin yükünü/Öldü benim karagücük eşeğim" (Artun 2000: 337) satırlarını ihtiva eden "Karagücük Eşeğim" adlı yalanlamaları dinleyen herkesi güldürüp eğlendirmektedir.

Kırgız yalanlamalarında da aynı durumdan söz etmek mümkündür. Nitekim Kırgız Adabiyatı Entsiklopediyalık Okuu Kuralı adlı eserde yalanlamaların, insanları eğlendirdiğinden bahsedilmektedir (2004: 102). Bunun yanında Kırgız folklorundaki "Gerçek İnsanı Vuran Sinek" adlı yalanlamanın "Yalan söyleyerek gencin, yaşlııı hoşuna gittim" ifadesiyle başlaması, söz konusu türün eğlendirme işlevi taşıdığını açık bir şekilde ortaya koymaktadır.

Yalanlama söyleyerek insanların gülüp eğlenmesini sağlayan anlatıcı, aynı zamanda dinleyenlerin ilgisini de çekmiş olur. Yukarıda da belirttiğimiz üzere yalanlamanın başka bir tür dahilinde yaşayan farklı bir çeşidi olduğu kanısına vardığımız masal tekerlemeleri bahsedilen bu durumla doğrudan ilişkilidir. Anlatacağı masala, yalanlama (masal tekerlemesi) ile başlayan bir anlatıı bu şekilde hem dinleyiciyi masalın olağanüstü dünyasına hazırlamış hem de onların dikkatini toplamış olur. Gerçekten de "Bir varmış, bir yokmuş. Evvel zaman içinde, kalbur saman içinde, deve tellal iken, sinek berber iken, katır çalgıcı, eşek köçek iken, ben babamın beşiğini tıngır mıngır sallarken." (Tezel 2009: 194) gibi bir yalanlama ile başlayan masalı (özellikle elektronik araçların olmadığı dönemlerde) kim dinlemek istemez ki? Bunun yanında yalanlamaların, dinleyicinin dikkatini toplama görevi sadece masallarla sınırlı tutulmamalıdır. Özellikle uzun halk hikayeleri ile meddahlıkta da dinleyicinin dağılan ilgisini toplamak için yalanlamalar vazgeçilmez bir araçtır (Köse 2002: 505).

Yalanlamalar, dinleyicilerin dağılan ilgisini toplaması kadar özellikle masalda bir imtihan aracı olarak kullanılması açısından da önemlidir. En inanılmaz yalanların söylenerek imtihanın kazanılması esasına dayanan bu durum, Stith Thompson'ın Motif Index of Folk Literature adlı eserinde "H. 509. 5. Yalan söyleme kabiliyeti" olarak yer almaktadır. Kırgız El Comoktoru (2013: 58-62) adlı eserde yer alan "Kalp" masalında da imtihan, yalan söyleme kabiliyetine dayanmaktadır. Masalda padişah, kırk tane inanılmaz yalanı söyleyen kişiye kızını vereceğini söyler ve bir çocuk, kırktan fazla yalan söyleyerek padişahın kızını almaya hak kazanır:

"Babam beni doğurduğunda ben dedemin at sürüsünü güttüm. Kırk kulaçlık kayın kemendim ve bindiğim kara benekli bir kısrağım var. Atları güderken uyuyuverdim, kısrağım kaçtı. Arayıversem koca bir ırmağın her yanına varıp doğurmuş. Tay yarıştırılan yer kadar uzak olsa da kırk kulaçlık kemendimi ortasına bağlayıp atlayarak geçtim. Kısrağımın yanına vardım, yavrusu yürümeye başlamış, öte beri koşturmakta. Yavrusunu

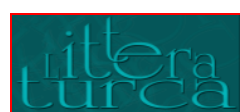

Journal of Turkish Language and Literature Volume:2, Issue: 1, Winter 2016, (1-12)

Doi Number: $10.20322 /$ It.06691 
alıp kısrağa binerek suyu geçeyim desem kısrağım adım atmaz. Çaresizce yavrusuna binip kısrağımı dehleyip sürdüm ve nehrin diğer yakasına çıktım. Inip otları kökleyip kısrağın ağız sütünü sağıp pişirip içeyim diye taştan ocak yapıp, tezek toplayıp, çakmağı çakıp tezeği tutuştursam yandığında pır pır edip uçmaya başladı. Meğerse o tezek sandığım, bıldırcınmış. Zar zor gayret edip bir ikisini yakaladım. Yeniden ateş yakıp, atların ağız sütünü pişirip, iki bıldırcının etini yiyip sütü içip bıldırcının yağı ile bir ayakkabımı yağlasam, diğerine yetmedi. Yağladığım ayakkabımı yastık edip, diğerini ayağımın altına koyup uyuya kalsam, ayağımdaki ayakkabı kaçıp gitti. Yola koyulup aradım. Varsam bir grup kişi arpa biçmekte. Birinin orağını alıp hızlıca arpa biçsem koca bir bıldırcın pır pır edip uçuverdi. Kıpkızıl orak ile öylece kalıverdim. Gebe bir bıldırcın imiş. Karın yağı ile böbrek yağı şırıldayıp akıverdi. Yavrusu da kıpkızı et şeklinde pır diye uçuvermesin mi? Bıldırcını alıp "Iş̧iniz kolay gelsin" diye orağı çiftçilere verip bıldırcını yağıyla-kemiğiyle yiyip doyduktan sonra kalanını saçıma bağlayıp ayakkabımı aramaya devam etsem gördüm ki su donup kalmıştır. Su içeyim diye tekme atsam su çıkmaz. Çaresiz kalıp kafamı boynumdan ayırıp kafamla buz çeksem sudan içip susuzluğum geçtikten sonra birisi: "Başı yok, başı yok" demekte. Başımı yoklasam, hakikaten yok. Meğerse demin buz çekip su içtiğim yerde unutmuşum. Geri dönüp başımı bulup boynuma yerleştirip ayakkabımı aramaya devam ettim. Bir obaya varsam kalabalık insanlar var. Orada toy vermekteler. Toyda benim kaçıp giden ayakkabım su doldurup misafirlere vermektedir. Onu orada tutup "Ne yaptığını sanıyorsun? Seni aramadığım yer kalmadı" dedim. "Sağ ayakkabını yağladın. Beni yağlamadığın için sana darıldım ve kaçtım" deyip itiraf etti. Ayakkabımı pataklayıp ikinci defa kaçmaması için yemin ettirdim ve tekrar at sürülerimin yanına geldim.

"Samet'in Nağıı" (Adıgüzel 2010: 37) adlı Azerbaycan masalında da karşımıza çıkan bu durum neticesinde yalan yarışını kazanan Kel Samet, padişahın büyük kızıyla evlenir.

Yalanın imtihan aracı olarak kullanıldığı bir başka tür ise fıkra olarak karşımıza çıkmaktadır. Erman Artun'un Karacabey fıkrası olarak tanıtıı̆ı "Yalan Yarışı" adlı fıkrada halk, Böcüoğlu ile Karacabey'den yalan söyleme konusunda yarışmalarını ister. Birinin söylediği yalanı, diğerinin yalanının alt etmesine dayanan yarışmayı Karacabey kazanır ve ortaya konan ödülü alır (Artun 2013: 17):

\section{Böcüoğlu:}

Konya'ya gidiyordum. Cebimde bir avuç pancar tohumu vardı. Giderken geçtiğim koyaklara saçarak gitmiştim. Konya'dan dönüşümde gözlerime inanamadım, koyaklar yemyeşil pancarla dolmuş.

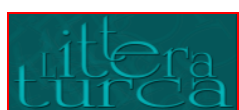


Karacabey:

Konya'ya gitmiştim. Ovanın bir ucundan öbür ucuna kadar uzanan, içinde yetmiş işçi, yetmiş ustanın çalıştığı ve bir işçinin sesini öbürünün duymadığı büyüklükte bakırdan bir kazan yapılıyordu. Kapısına yanaşarak usta başına "Bu kadar büyük bir kazan ne olacak?" diye sorduğumda Böcüoğlu'nun pancarları pişecek" diye cevap verdi.

Aynı durumu bir Kayserili fıkrasında da görmekteyiz. Yalanlama türüne özgü özellikler bulunmasa da söz konusu türden etkilendiğini düşündüğümüz bu fıkraya göre kendisine yalan söylemeyi başarabilene bir küp dolusu altın vermeyi vaat eden padişah, ilk üç kişinin yalanlarına inanmamasına rağmen Kayserilinin yalanına inanmak zorunda kalır ve altını ona verir:

Padişahın biri "Bana yalan söyleyebilene bir küp dolusu altın vereceğim" demiş. Yalancılar, hemen saraya koşuşturup başlamışlar yalana: IIlk yalancı "Bir kuş, aslanı kapıp yuvasına götürdü." demiş. Padişah: "Bunun neresi yalan? Kuş kartaldır, arslan da kuzu kadar minik bir yavru. Kaptı mı götürür tabii" demiş. İkinci yalancı "Komşu ülkede bir eşeği kral yaptılar" demiş ve padişah "Üıkenin kralı, pencereden bakınırken tacını düşürmüş. Taç da pencerenin altındaki eşeğin başına geçmiş. Taç kimin kafasındaysa, kral odur tabii" demiş. Üçüncü yalancı da "Padişahım, ben gökyüzüne bir ok attım. Altı ay sonra geri döndü" demiş. Padişah "Ok bir ağacın üstüne düşmüştür. Ağaç, sonbaharda yapraklarını dökünce takılacak yer bulamayıp yere inmiştir." demiş. Böylece padişah, her yalana gerçek bir bahane bulmuş ve kimse padişaha bu yalandır dedirtememiş. Ama bir gün bir Kayserili gelmiş ve "Padişahım, sen benim babamdan borç olarak bir küp dolusu altın almıştın. Şimdi geri almaya geldim. Yalandır dersen ödülümü ver. Yalan değil dersen borcunu öde" (K-1)

Yalanlamalar, aşıkların gücünü tayin etmek için de kullanılmıştır (Kaya 2007: 88). En bulunamaz nitelikteki yalanların bir araya getirilmesiyle oluşturulan bu "atışmalı yalanlama"lar, aşık edebiyatımızda çok fazla yer almamıştır. En meşhurları Püryani-Çobanoğlu (Kaya 2000: 224) ile Kara Mehmet-Şıhlıoğlu atışmaları olup söz konusu atışmaların ikincisinin bir bölümü aşağıdadır (Artun, yayın t. yok: 11):

Şıhlıoğlu:

Yatsan bile gene girmez düşüne

Hiç aklım ermedi bunun işine

Halat atmış Erciyes'in başına

Çeke çeke bölen gördüm ne dersin?

\section{Kara Mehmet:}

Kuyruğundan tuttum bak kova kova

Öldürürüm onu ben döve döve

Altı koyun yutmuş iki de deve

Bir küçücük yılan gördüm ne dersin?

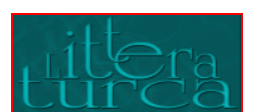

Journal of Turkish Language and Literature

Volume:2, Issue: 1, Winter 2016, (1-12)

Doi Number: 10.20322/lt.06691 
Acep ne dersin ki sen bu hususta

Bir yanı atlıya bir yanı posta

Bilmem mühendisti bilmem bir usta

Karıncada plan gördüm ne dersin?
Kara Mehmet der de değilim cahil

Caniye caniyim, ehile ehil

Yalan idim ama bu kadar değil

Seni benden yalan gördüm ne dersin?

Yalan söylemek; ayıp, günah ve tasvip edilmeyen bir eylem olarak bilinir. Kişinin gerek maneviyatını gerekse toplumla olan ilişkisini doğrudan ve olumsuz olarak etkileyen yalan, bütün inanç sistemlerince yasaklanmış; göksel dinler tarafından "büyük günah"lardan biri kabul edilmiştir. Yalan söyleme eylemini gerçekleştiren kişi, ayıplanma ve gruptan soyutlanma gibi yaptırımlara maruz bırakılabilmekte ve hem sosyal yaşantısı itibariyle hem de inançsal bağlamda bunun doğurduğu sonuçlarla psikolojik olarak baskı altında kalabilmektedir. Bu psikolojik baskıyı yalanlama söyleyerek aşabilen aşık yahut anlatıcı, başka bir deyişle yüceltme savunma mekanizmasını kullanarak dinleyicilerin gözlerinin içine baka baka bu ayıp/günah olarak nitelendirilen eylemi rahatça gerçekleştirebilmekte ve böylece yalan söylemenin getirdiği kişisel, toplumsal ve dinsel baskılardan kurtulabilmektedir:

"Babam doğarken dedemin at sürüsünü gütmekteydim. Doğurmamış kısrağı sağıp, ilerideki kımızı kabına koyup, içmeden sarhoş oldum. Çıkmamış ağacın dallarından sırık yapıp örülmemiş iple bağladım. Çıkmamış madenin dibinde doğmamış tavşan yatmaktaymış. Yapmadığım değnek ile bir vurdum, daha kazılmamış yuvasına kaçıverdi. Üç tane arık gördüm: ikisi kuru, birinin suyu yok. Üç arıkta üç balık varmış; ikisi ölü, birinin canı yok. Orada üç kişi varmoş: Ikisi çıplak, birinin giysisi yok. O çıplağın eteğine canı olmayan balığı koyuverdiğimde, üç ev gördüm: ikisinin çatısı yok, birinin üstü açık. O üç eve girdiğimde orada üç kazan durmaktaymış: ikisinin dibi delik, birinin dibi yok. Dibi olmayan kazana canı olmayan balığı koyarak pişirip yemeden doydum." (Baldar Folkloru 2002: 127)

Erman Artun'a göre (1996: 33) yalanlamaların bir bölümü sosyal içeriklidir ve aşık, yaşadığı dönemin haksızlıklarına, yolsuzluklarına ve geriliklerine yönelik göndermeler yapar. Aşık, kişide ve sosyal alanda görülen toplumun değerlerine aykırı her durum ve davranışı mizahi bir anlatımla yalanlamasında yer verebilir. Yalanlamanın, bir nevi, protesto işlevine dikkat çeken araştırmacı, buna örnek olarak ise Kara Mehmet'in "Tokdur Bey" ve "Karagücük Eşeğim" adlı yalanlamalarını gösterir.

Anadolu ve Kırgız sahası yalanlamalarının çeşitli fonksiyonlara sahip olduğu açıkça görülmektedir. Aşık/anlatıcı, yalanlama söyleyerek hem dinleyenlerin gülüp eğlenmesini sağlayabilmekte hem de masal, hikaye vs. anlatırken dağılan ilgilerini toplayabilmektedir. Yalanlamalar, farklı türler içerisinde yaşayarak hem kahramanın aşmak zorunda olduğu bir imtihan aracı hem de masalın olağanüstü dünyasına bir giriş aracı niteliğine bürünmektedir. Anlatıcı, yalanlamalar sayesinde psikolojik olarak rahatlarken aynı zamanda toplumun aksaklıklarına dikkat çekerek onları protesto edebilmektedir. Tespit edebildiğimiz bu işlevlerin bir kısmı, W.

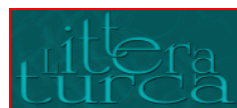

Journal of Turkish Language and Literature

Volume:2, Issue: 1, Winter 2016, (1-12)

Doi Number: 10.20322/It.06691 
Bascom'un söz konusu işlev modeli dahilinde bulunmakta iken bazıları ise yalanlama türüne özgü bir özellik göstermektedir.

\section{Sonuç}

İncelememiz neticesinde görülmektedir ki yalanlamalar, Kırgız folkorunda müstakil ve manzum olarak bulunmakla birlikte bazı masalların bünyesinde de yaşamaktadır. Hem güldürüp eğlendiren hem de imtihan aracı olarak kullanılan yalanlama, tarihi serüveni içerisinde Anadolu Türk halk edebiyatına da aksetmiş ve aşık fasıllarında çokça kullanılan bir tür haline gelmiştir. Toplumun sorunlarını mizahi bir biçimde dile getiren yalanlamalar, aynı zamanda aşığın içinde bulunduğu psikolojik baskıdan da kurtulabilmesini sağlamış; güldürü unsuru özelliğiyle de dinleyicilerin ilgisini çekmede kullanılmıştır. Yalanlamalar, Anadolu'da aşık edebiyatı dışında anonim halk edebiyatı ürünleri dahilinde de günümüze kadar gelmiştir. Türkü, masal, fıkra ve tekerleme gibi türlerin içinde yaşayan yalanlamalar, son dönemlerde, özellikle elektronik iletişim unsurları ile tekrar müstakilleşmeye başlamıştır.

\section{Kaynakça}

ADıGÜZEL, Sedat, (2010), "Batı Azerbaycan Masallarında Yarış ve Rekabet Örnekleri", Acta Turcica", Yıl: 2, S. 1, 30-38.

AKMAN, Eyüp, (2013), "Kastamonu Türküsü 'Tiridine Bandım' Şathiye Midir?", IV. Uluslararası Türk Kültürü Kurultayı, 449-459.

ARI, Bülent, (2013), "Güldürücü Destanlardan Yalanlamalı Destanlar İle Gelin-Kaynana Manilerinin Mizah Yönünden Benzerlikleri", Turkish Studies, C. 8, S. 8, 53-64.

ARTUN, Erman, (1996), Adana Aşıklık Geleneği (1966-1996) ve Aşık Feymani, Adana: Hakan Ofset.

ARTUN, Erman, (2000), Adana Halk Kültürü Araştırmaları, Adana: Altınkoza Yayınları.

ARTUN, Erman, (2013), "Çukurova Yerel Fıkra Tiplerinin Türk Fıkra Anlatma Geleneğindeki Yeri", VIII. Milletlerarası Türkoloji Kongresi Basılmamış Bildiri Metni, 1-24, www.turkoloji.cu.edu.tr, Erişim T. 31.10.2015

ARTUN, Erman, (yayın t. yok), "Ceyhanlı Aşık Karamehmet'in Yalanlamaları", 1-12, www.turkoloji.cu.edu.tr, Erişim T.: 03.12.2015

Baldar Folkloru, (2002), (Tüzgön: Güldara Orozava), Bişkek: Şam Basması.

BAŞGÖZ, İlhan, (1996), "Protesto: Folklorun Beşinci İşlevi (Fonksiyonu)", Umay Günay Armağanı, Ankara: Feryal Matbaacılık, 1-4.

BORATAV, Pertev Naili, (2000), Tekerleme, İstanbul: Tarih Vakfı Yayınları.

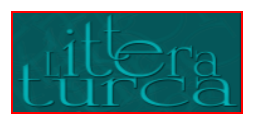

Journal of Turkish Language and Literature

Volume:2, Issue: 1, Winter 2016, (1-12)

Doi Number: 10.20322/lt.06691 
CERRAHOĞLU, Münir, (2011), "Yalanlamalı Destanlar ile Masal Tekerlemelerinin Benzerlikleri", Mustafa Kemal Üniversitesi Sosyal Bilimler Enstitüsü Dergisi, C. 8, S. 15, 281-293.

ÇOBANOĞLU, Özkul, (2000), Aşık Tarzı Kültür Geleneği ve Destan Türü, Ankara: Akçağ Yayınları.

DUYMAZ, Ali, (2002a), Irranı Arzulayan Sözler Tekerlemeler, Ankara: Akçağ Yayınları.

DUYMAZ, Ali, (2002b), "Türk Halk Serinde Gerçeküstü Destanlar Üzerine Bir Değerlendirme", Balıkesir Üniversitesi Sosyal Bilimler Enstitüsü Dergisi, C. 5, S. 8, 107-121.

EKici, Metin, (2011), Halk Bilgisi (Folklor) Derleme ve Inceleme Yöntemleri, Ankara: Geleneksel Yayıncılık. GÜNAY, Umay, (1999), Türkiye'de Aşık Tarzı Şiir Geleneği ve Rüya Motifi (3. Basım), Ankara: Akçağ Yayınları.

GÜVENÇ, Ahmet Özgür, (2014), "Internet Folkloru Üzerine Önerilen Bir Terim: e-folklor", Atatürk Üniversitesi Sosyal Bilimler Enstitüsü Dergisi, 18 (2), 31-46.

KARAKÖSE, Saadet, (2014), "Yalancı Şairin Gözüyle Yalana Bakış: Klasik Edebiyatımızda Yalan", TAED, 127-169.

KAYA, Doğan, (2000), "Aşık Püryani'nin Karşılamaları", Aşık Edebiyatı Araştırmaları, İstanbul, 213-230.

KAYA, Doğan, (2007), Ansiklopedik Türk Halk Edebiyatı Terimleri Sözlüğü, Ankara: Akçağ Yayınları.

Kırgız Adabiyatı Entsiklopediyalık Okuu Kuralı, (2004), (Başkı Redaktor: Ü. Asanov), Bişkek: Mamlekettik Til Cana Entsiklopediya Borboru.

Kırgız El Comoktoru, (2013), (Cıynaktı Tüzgön: Külüypa Turganbayeva), Bişkek: Canızak Basma.

Kırgız Etnografiyası Boyunça Sözdük, (2005), (Tüzgöndör: O. K. Karataev, S. N. Eraliev), Bişkek: Biyiktik.

KÖSE, Nerin, (2002), "Tür ve Fonksiyon", Uluslararası Türk Dünyası Kurultayı Halk Edebiyatı Kongresi Bildirileri, Ankara: Kültür Bakanlığı Yayınları: 2955.

TEZEL, Naki, (2009), Türk Masalları, İstanbul: Bilge Kültür Sanat Yayınları.

www.uludagsozluk.com, Erişim T.: 31.10.2015.

(K-1): İsa Yücel, 55 yaşında, Lise mezunu, Emekli, Samsun doğumlu, Yalova'da yaşıyor, Arkadaşından duymuş, Görüşme T.: 06.09.2015

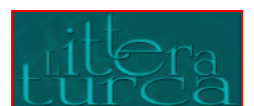

Journal of Turkish Language and Literature

Volume:2, Issue: 1, Winter 2016, (1-12)

Doi Number: 10.20322/It.06691 


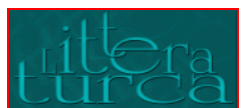

Journal of Turkish Language and Literature

Volume:2, Issue: 1, Winter 2016, (1-12)

Doi Number: $10.20322 /$ It.06691 